\title{
Nerealizované věžové vodojemy
}

\section{ROBERT KOŘíNEK, ALENA KRISTOVÁ}

Klíčová slova: věžový vodojem - nerealizovaný návrh - projekt

\section{SOUHRN}

Předložený príspěvek uvádí několik případů nerealizovaných projektů věžových vodojemů na území České republiky. Zabývá se technickým řešením neuskutečněných objektů a zároveň uvádí, jaké důvodu vedly projektanty, úřední orgány nebo investory k hledání jiného řešení. V závěru se snaží stručně zamyslet nad hodnotami, které byly realizací nových projektů místo původně navržených získány, či naopak ztraceny.

\section{ÚVOD}

Součástí většiny vodovodních systémů bývá vodojem - bud’ zemní, nebo věžový. Při projektových prípravách a řešení otázky technického i vizuálního návrhu samotného objektu vodojemu vznikly v některých prípadech varianty, které z určitých důvodů nebyly nakonec realizovány. Některé z těchto prípadů jsou dále podrobněji popsány včetně uvedení důvodů, proč se původní projektový návrh neuskutečnil.

Ke změnám v projektových dokumentacích samozřejmě často docházelo během úředního schvalovacího procesu nebo i v prủběhu výstavby vodovodu/vodojemu. Jednalo se však zpravidla o drobnější úpravy, které mohly z různých důvodů $v$ průběhu výstavby vyplynout a jejich realizací nedošlo k významné změně ve vzhledu nebo funkčnosti objektu. Tyto případy nejsou $\checkmark$ příspěvku uvažovány jako nerealizované. Přesto uvádíme jeden zajímavý př́ipad, kdy zdánlivě malá změna v průběhu stavby měla zásadní dopad na autorství architektonického návrhu.

\section{INFORMAČNÍ ZDROJE}

Hlavním zdrojem potřebných informací k nalezení nerealizovaných projektů věžových vodojemů a vysvětlení prríčin jejich neuskutečnění jsou v první řadě dostupné fondy státních a soukromých archivů. U niže prèedstavených projektů jsou to zejména fondy měst a obcí, fondy okresních úruadů a fondy uložené v Archivu Národního technického muzea v Praze.

Dalšími zdroji informací jsou dobové literární zdroje a osobní průzkumy objektů, které byly místo původně navržených realizovány. Jako doplňkový zdroj informací pak slouží paměti a vzpomínky osob.

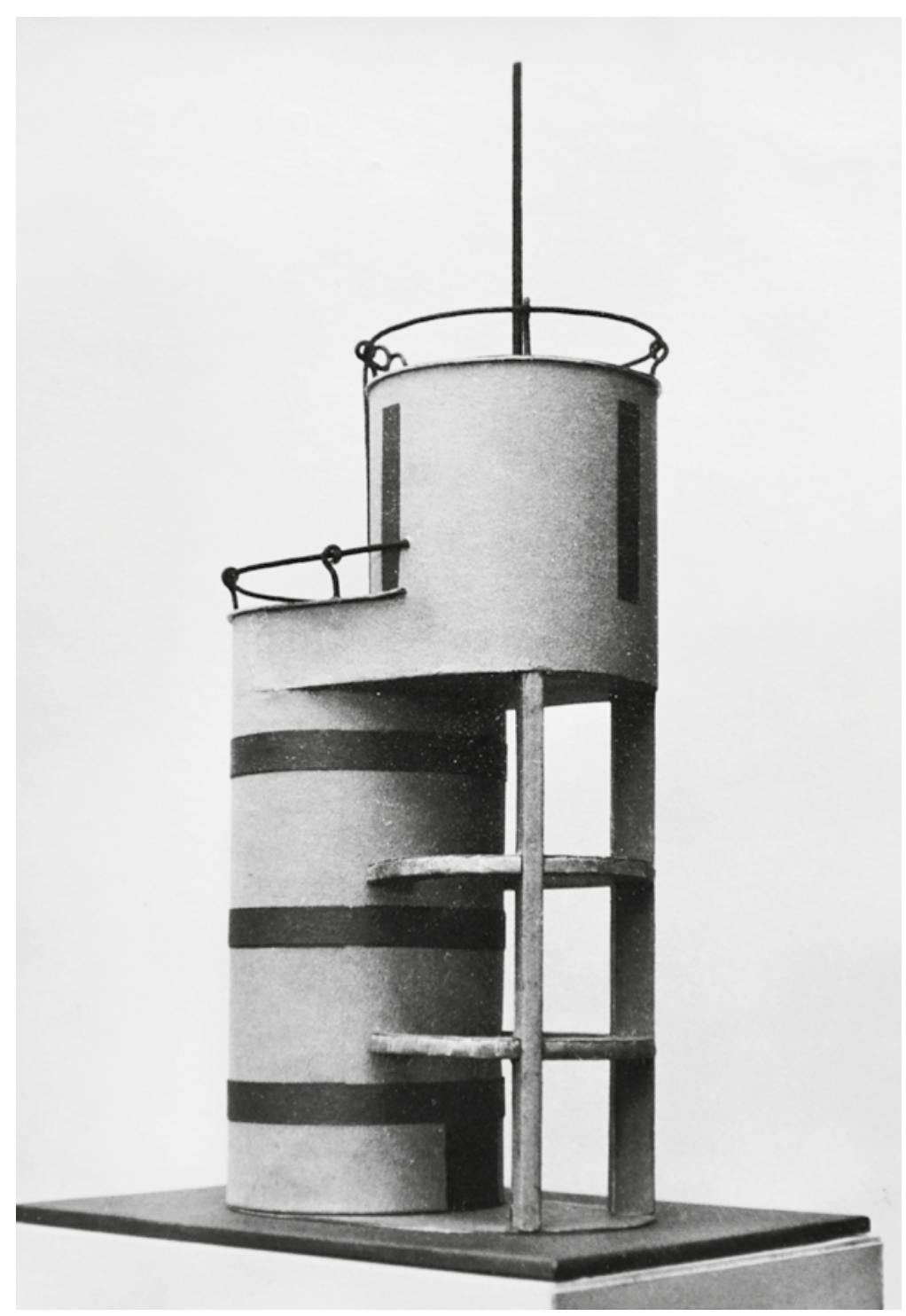

Obr. 1. Původní návrh věžového vodojemu architekta Vojtěcha Vanického pro seřad’ovací nádraží [3]

Fig. 1. The original design of the elevated water tank by the architect Vojtěch Vanický for the marshalling yard [3] 


\section{PŘÍKLADY NEREALIZOVANÝCH PROJEKTU゚}

\author{
Rybník - seřad’ovací nádraží Česká Třebová
}

Návrh projektu na výstavbu nového seřad’ovacího a topírenského nádraží v České Třebové (část seřad’ovacího nádraží leží na katastrálním území obce Rybník) pochází z července 1929. Protože bylo nutno zajistit nové zdroje vody pro provoz nádraží, vypracovala firma Ing. Bohumil Belada, úředně autorizovaný civilní inženýr stavební z Prahy na základě zadávacího listu Ředitelství státních drah Praha-Jih ze dne 29. srpna 1929 detailní návrh nového vodovodu ze dvou vodních zdrojů - pitná voda se přiváděla z pramene Vrbovky, voda užitková z řeky Třebovky. Součástí nového vodovodu byl věžový vodojem pro dvě nádrže, který architektonicky navrhl profesor první státní průmyslové školy v Plzni architekt Vojtěch Vanický. Jeho první návrh se datuje k červenci roku 1930.

Železobetonová nádrž s vypouklým dnem (15 metrů nad okolním terénem) na užitkovou vodu měla být nesena čtveřicí železobetonových piliřru. Konstrukce pod nádrží měla být vyzděna a měla tvořit uzavřený válec (systém stěnový). Druhá, výše položená nádrž s rovným dnem na vodu pitnou, měla mít dva nosné piliře společné se spodní nádrží, dva další pilî̌re pak měly být realizovány jako otevřená konstrukce (systém skeletový). Střechy nad oběma nádržemi měly mít terasy se zábradlím (ve výšce 22 a 28 metrů) vzájemně spojené žebríkem (obr. 1).

Ředitelství státních drah Praha-Jih však požadovalo přepracování projektu: „Veškeré pozemni stavby bud'tež vyřešeny způsobem nejjednodušším a nejúčelnějším. Architektonické rešení musí vyplývat z konstrukce. Excentrické umistění nádrže pitné vody nad nádrží vody užitkové nezvyšuje nikterak účelnost řešení a bylo by značně drahé." Upustit se rovněž mělo od torkretování (řešení izolace stěn objektu), provedení oken po celém obvodu vodojemu a železobetonová schodiště byla změněna na ocelová. Přepracování projektu provedla opět firma inženýra Belady v průběhu roku 1931 [1].

Realizovaný návrh věžového vodojemu je řešen jako válcová stavba s šesticí nosných železobetonových piliřru nesoucí nádrže nad sebou (obr. 2). Konstrukce je vyzděna neomítanými dutými cihlami, výška celého objektu odpovídá výšce původního návrhu, vnější průměr válce činí 9,5 metru. Nádrž na užitkovou vodu má objem $150 \mathrm{~m}^{3}$, nádrž na vodu pitnou 100 m³. Stavební části zdejších vodárenských objektů provedly pražské firmy B. Brát a Ing. Kdoul \& Dr. Pittl, strojní vybavení dodaly firmy Královopolská továrna na stroje, Brown-Boveri, a. S., Brno, Lanna, a. S., Praha a Sulz a Pech Praha [2].

\section{Nový Hradec Králové}

Ve třicátých letech 20. století řešil městys Nový Hradec Králové výstavbu vodovodu. Projekt vypracovaný firmou Ing. Dr. František Uher z Peček počítal s objektem věžového vodojemu železobetonové nosné konstrukce (kombinace systému stěnového a skeletového) umístěném na Kopci Sv. Jana (katastrální území Třebeš). Konstrukci měly tvořit čtyři pilíre ukotvené do základové desky nesoucí ve výšce 24 metrů nad terénem nádrž objemu $320 \mathrm{~m}^{3}$. Středem celého objektu měl vést dřík se schodištěm a potrubím, který byl ukončen až na střeše vodojemu. Ze schodiště se ve třech výškových úrovních (5, 11 a 17 metrů nad terénem) přistupovalo na venkovní ochozy. Vodojem byl umístěn na místě bývalého kostela a zároveň na místě, odkud se měl stát významnou pohledovou dominantou širokého okolí - a tyto skutečnosti byly pro jeho konečný vzhled zásadní.

Proto při vodoprávní komisi v roce 1935 bylo dohodnuto, že architektonický návrh věžového vodojemu bude predložen také městské radě Hradce Králové. Ta o vyjádření požádala osvětovou a uměleckou komisi, jejiž stanovisko znělo: "Budiž predložen nový návrh odpovídající následujicím požadavkưm... režné zdivo budiž červené, reservoir a nátěry oken a mřižoví v barvě šedozelené. Tvar vlastního

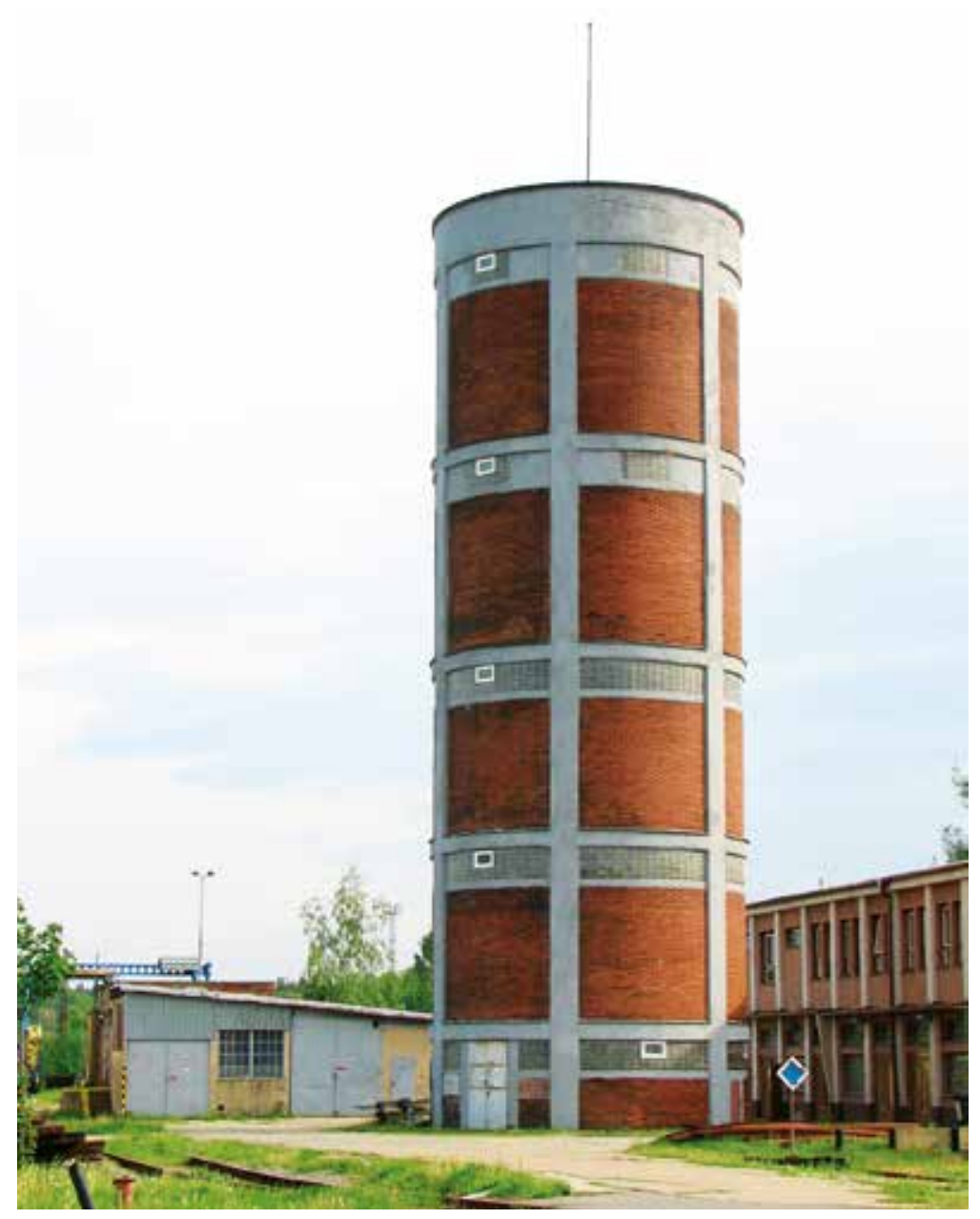

Obr. 2. Realizovaný věžový vodojem pro seřad’ovací nádraží (2012)

Fig. 2. Implemented elevated water tank for marshalling yard (2012)

reservoiru pripomínejž svojí silhuetou formu kalichovitou, ochozový balkon pod reservoirem budiž vyřešen úměrně vzhledem k žádanému tvaru vlastního reservoiru."

Objekt tak zásadně změnil svůj původní vzhled, změny doznala i konstrukce (obr. 3). Úpravu provedla firma, která vodojem také vystavěla - Václav a František Capoušek, stavitelství Hradec Králové (na stavbě vodovodu se dále podílely firmy Josef Drahoš, stavební inženýrství a stavitelství ve Vysokém Mýtě a Ing. K. Krix, úředně autorizovaný civilní inženýr v Litomyšli). A změnu ocenil také tisk, konkrétně Lidové noviny: „Vodárenská věž pomníkem a rozhlednou. Nový Hradec Králové staví právě vodovod, jehož voda se bude čerpat výtlačným potrubím na vodárenskou věž na kopci sv. Jana. Věži bude však dána zevní podoba kalicha na pamět toho, že pưvodní kostel na tomto vrchu byl zasvěcen památce kostnických mučedníků Mistra Jana Husa a Jeronýma Pražského." [4].

Nosnou část válcového dř́ku realizovaného vodojemu tvoří cihelné neomítané zdivo, pod prostorem akumulace se nachází vyhlídková plošina. Prostor akumulace připomínající zmíněný kalich je hladce omítnut a nese tři horizontální pásy. Objem nádrže nově navrženého vodojemu zůstal zachován, celková výška po vrchol lucerny je 38,5 metru [5].

\section{Bělá pod Bezdězem}

Projekt skupinového vodovodu pro město Bělou pod Bezdězem s osadami Podolí, Vazačka a Přední a Zadní Hlínoviště vypracovala významná česká vodárenská firma Ing. Jaroslav Matička z Prahy-Karlína. V projektu, který byl 


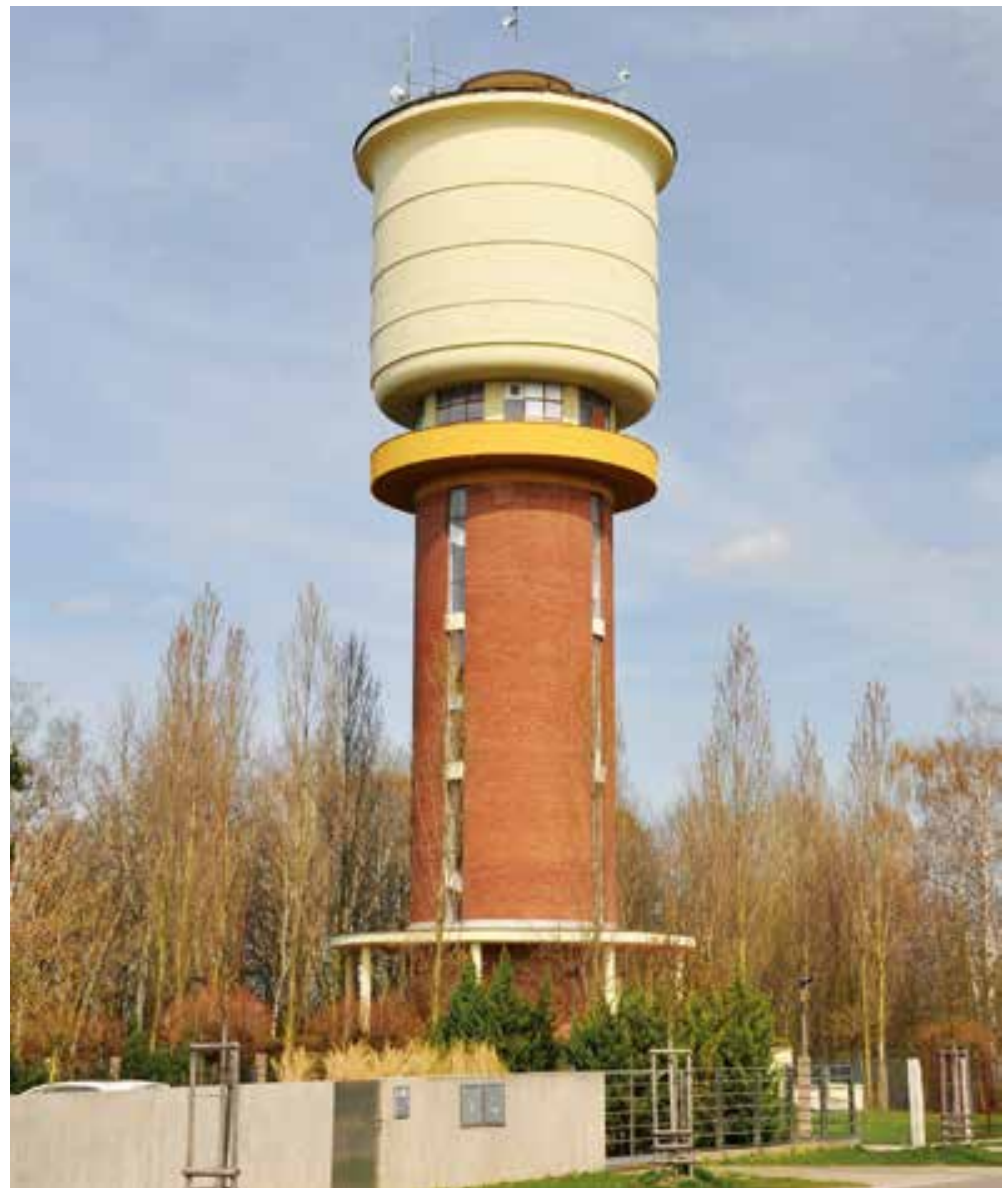

Obr. 3. Věžový vodojem pro Nový Hradec Králové (2015)

Fig. 3. Elevated water tank for Nový Hradec Králové (2015)

zástupcům města předán v polovině roku 1924, bylo počíáno s jedním věžovým vodojemem v místě nového sídliště rodinných domků v západní části Bělé. Vodojem svým vzhledem odpovídal tehdejším Matičkovým návrhům v historizujícím stylu (obr. 4). Stavitel vodovodu Juránek jej označil za archaický a présvědčoval městské zastupitele, aby se podoba vodojemu změnila a ten „odpovídal době výstavby, místu a na pozadí Bezdězu byl dominantou města“. Jeho slova byla vyslyšena a novou funkcionalistickou podobu objektu vtiskl významný český architekt František Janda, žák dalšího významného českého architekta Jana Kotěry [6]. A jak uvádí dobová zpráva, změna to byla pozitivní: „Silhueta její prispívá svým tvarem celkovému pohledu na město Bělou, kde v pozadí jsou oba kužele Velkého a Malého Bezděze, svým vhodným profilem - to u věži nově stavěných stává se velmi zrídka."

Nosná konstrukce věžového vodojemu je železobetonová s výplňovým režným zdivem (obr. 5). Objekt je pohledově po výšce rozdělen na čtyři části - príizemní část se zastřešeným ochozem (součástí projektu bylo také vybudování parku v okolí vodojemu a zastřešení mělo sloužit návštěvníkům parku v případě deštivého počasí), válcový dřík se šesticí nosných polopiliřů, prostor akumulace s nádrží objemu $160 \mathrm{~m}^{3}$ a jehlancovou střechu se čtveřicí vikýřù.

Součástí celého systému se stal také věžový vodojem v Hlínovišti, původně navržený jako "nadzemní. Přezkoušením celého projektu technickou komisí zemědělské rady však bylo konstatováno, že vhodnější bude postavit vodojem věžový. I ten byl navržen architektem Jandou.

Vodojem v Bělé již neslouží od roku 1967 k akumulaci vody, v přízemní části je však stále v provozu přečerpávací stanice. Vodojem v Hlínovišti je v provozu stále [7-9].

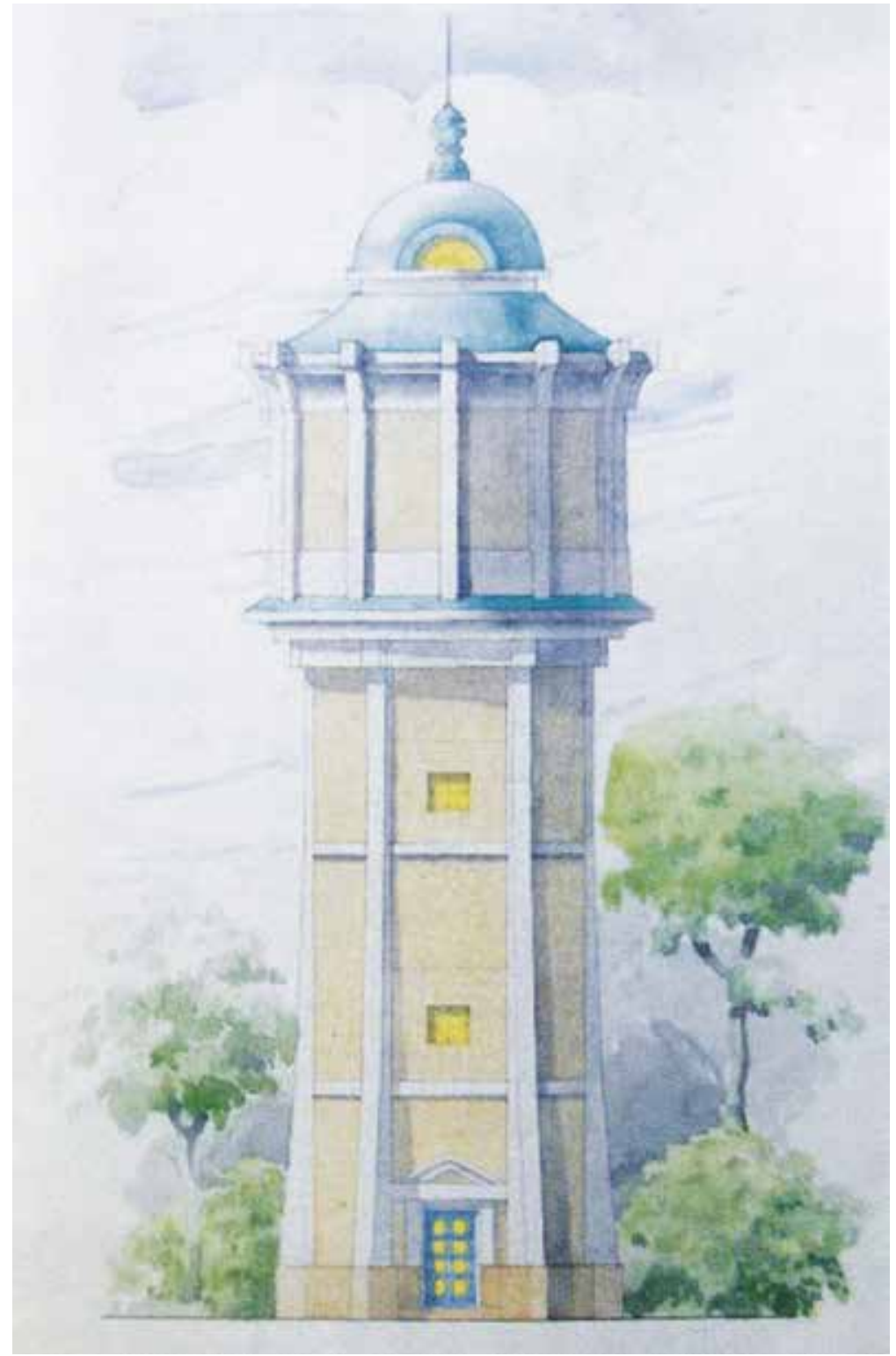

Obr. 4. Matičkův nerealizovaný návrh věžového vodojemu v Bělé pod Bezdězem [9] Fig. 4. Matička's unrealized design of the elevated water tank in Bělá pod Bezdězem [9]

\section{Poděbrady}

Architekt František Janda není podepsán pouze pod věžovými vodojemy v Bělé pod Bezdězem. Podle jeho návrhů byla na našem území postavena celá řada těchto objektů, jeden z nich se nachází v Poděbradech [10].

Na počátku dvacátých let 20. století začalo město Poděbrady řešit nedobrou situaci se zásobováním pitnou vodou. Z dopisu Lázní Poděbrady adresovaného dne 31. srpna 1921 městské radě vyplývá, že Poděbrady v té době neměly $v$ rámci vodovodu žádný vodojem ( $v$ nočních hodinách, když se voda do trubní sítě nečerpala, tak byly Poděbrady prakticky bez vody). Proto město v roce 1924 po úspěšných sondovacích a čerpacích pokusech oslovilo vodárenské firmy s nabídkou vypracovat detailní projekt vodovodu. Nakonec byl vybrán projekt další významné vodárenské osobnosti u nás, profesora ČVUT v Praze Jana Vladimíra Hráského. A jelikož městská rada požadovala věnovat zvýšenou pozornost vzhledu věžového vodojemu, oslovila architekta Františka Jandu, který již dřive s městem úzce spolupracoval. 


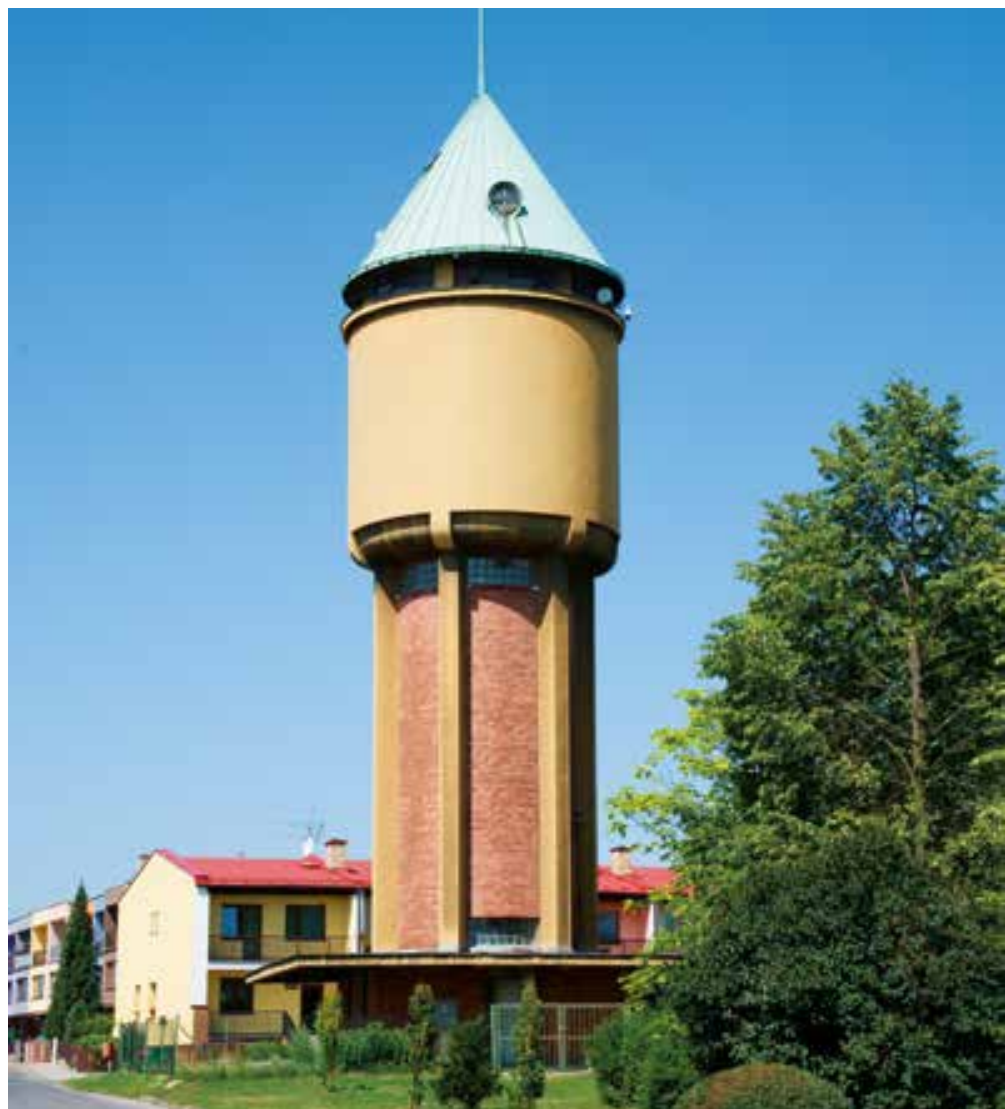

Obr. 5. Věžový vodojem podle návrhu architekta Františka Jandy (2019)

Fig. 5. Elevated water tank designed by architect František Janda (2019)

Původní Hráského návrh samotné železobetonové nádrže vodojemu byl revoluční - ta měla být kulová, resp. mělo se jednat o dvě soustředné kulové nádrže [11]. Technická kancelář rady zemědělské pro Čechy dne 25. listopadu 1926 tento návrh sice uznala jako vhodný, když napsala že: "koule jest bezesporu nejúspornějši nádoba a také její statický výpočet nemǔže působiti potiže". Zároveň však následně dodává: „Jinak však jest s prováděním, uvážíme-li, že nutno vybedniti, železnou armaturou presně opatřiti a betonem vydusati ve výši 30 až 40 metrů nad zemí dvě soustředné železobetonové koulové nádoby o prüměrech 10 a 13 metrů. Neni pochyb, že by se při známé dovednosti našich tesařských mistrů vybednění podařilo, leč ostatní práce - uložení armatur a vybetonování nepropustných tenkých stěn - jsou velmi těžko proveditelné, ač-li by se na tuto práci vůbec našla firma, která by chtěla vzíti záruku." [12].

Muselo tak dojít k přepracování projektu věžového vodojemu do dnešní podoby s válcovou nádrží. Architektonických návrhů vypracoval Janda několik (obr. 6).

Práce na téměř 44 metrů vysokém vodojemu započaly v dubnu 1929, téhož roku byl objekt dokončen. Prízemní část je pro Jandu typicky řešena se zastřešenou kolonádou (vodojem je podobně jako Bělský opět umístěn v parku), obvodová zídka kolonády nese žlaby pro okrasné květiny (a jak dokládají dobové snímky, skutečně $v$ nich byly umístěny). Nosná konstrukce objektu je zděná z cihel, železobetonová nádrž má objem 400 m³ (obr. 7).

Profesor Hráský však myšlenku kulové nádrže neopustil. Pokusil se tuto nádrž prosadit také při projektování vodovodu pro město Kolín. Ani zde však neuspěl a tak se na doporučení Zemského úřadu z roku 1929 provedla opět železobetonová nádrž válcového tvaru [13].
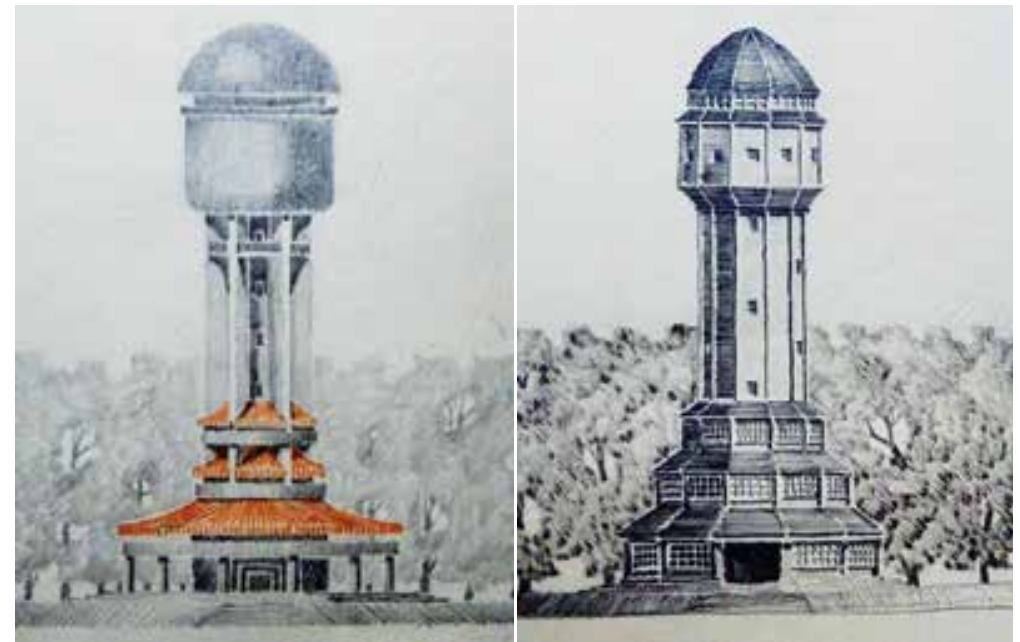

Obr. 6. Dochované vybrané nerealizované návrhy Františka Jandy věžového vodojemu $\checkmark$ Poděbradech [14]

Fig. 6. Preserved selected unrealized designs of František Janda elevated water tank in Poděbrady [14]

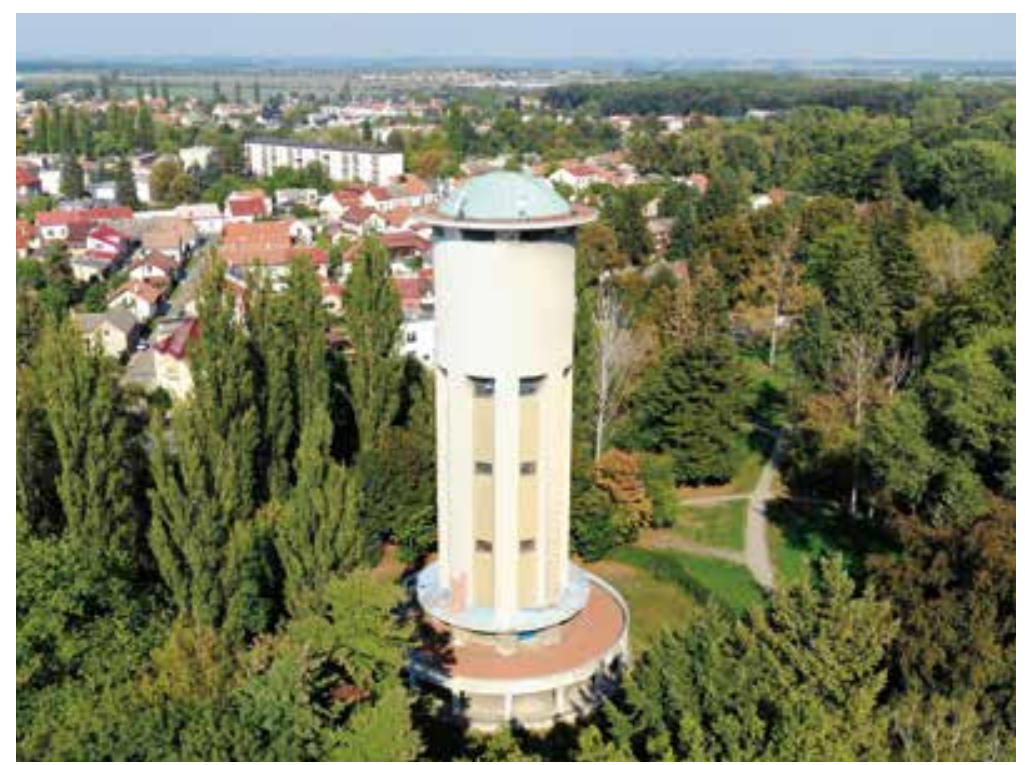

Obr. 7. Poděbrady na pozadí věžového vodojemu (Ondřej Civín, 2018)

Fig. 7. Poděbrady on the background of the elevated water tank (Ondřej Civín, 2018)

\section{Zamachy a Bílá Hlína}

Z roku 1908 pochází projekt firmy Pekař a Vačkař, první česká továrna na pumpy a vodovody z Prahy-Karlína na stavbu vodovodu pro obec Zamachy a osadu Syslov. Stavební rozpočet akce byl stanoven na téměř 55 tis. Kč, čímž přesahoval možnosti této malé obce (Zamachy společně s Osadou Syslov měly v té době 230 obyvatel). Zemskou a státní subvenci se získat nepodařilo, takže projekt se nakonec nerealizoval.

Jeho součástí měl být malebný věžový vodojem (obr. 8). Nosná zděná část kruhového půdorysu nesla ocelovou nádrž ze „štýrského plechu» o obsahu $30 \mathrm{~m}^{3}$ uloženou na železobetonovém stropě 10 metrů nad okolním terénem. Stěny kolem prostoru akumulace byly navrženy z 15 centimetrů tlustého hrázděného zdiva, půdorys byl osmiboký. Vstup k nádrži byl řešen točitým schodištěm uvnitř dř́ku, neseným třemi železobetonovými podestami vetknutými do konstrukce dříku. 


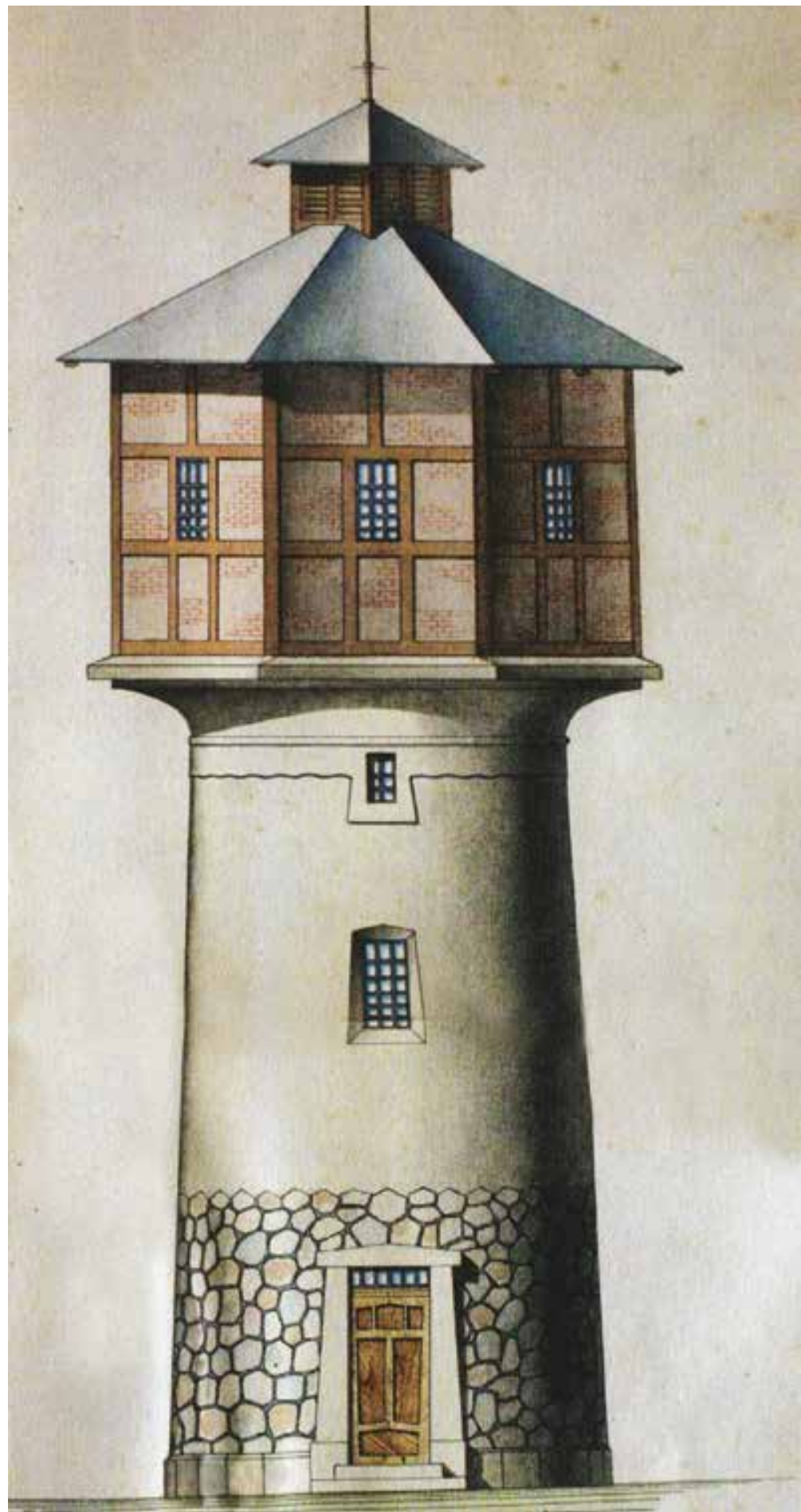

Obr. 8. Nerealizovaný věžový vodojem firmy Pekař a Vačkař pro vodovod obce Zamachy [15] Fig. 8. Unrealized elevated water tank of company Pekař and Vačkař for the water supply of the village Zamachy [15]

Vodovod se v obci nakonec realizoval, a to $v$ roce 1913, kdy jej vystavěla firma Artesia. Věžový vodojem nahradil vodojem na nosné konstrukci výšky 2,2 metru. Jak se následně ukázalo, pro potřebné tlakové poměry v síti to byla výška nedostačující [15].

Ze stejné doby pochází projekt na vybudování vodovodu v Bílé Hlíně. Na zasedání osadního výboru 9. řijna 1907 řekl v zahajovacím projevu starosta Josef Švarc k donášení a dovážení vody, že "zlu tomuto dlužno konečně odpomoci”.

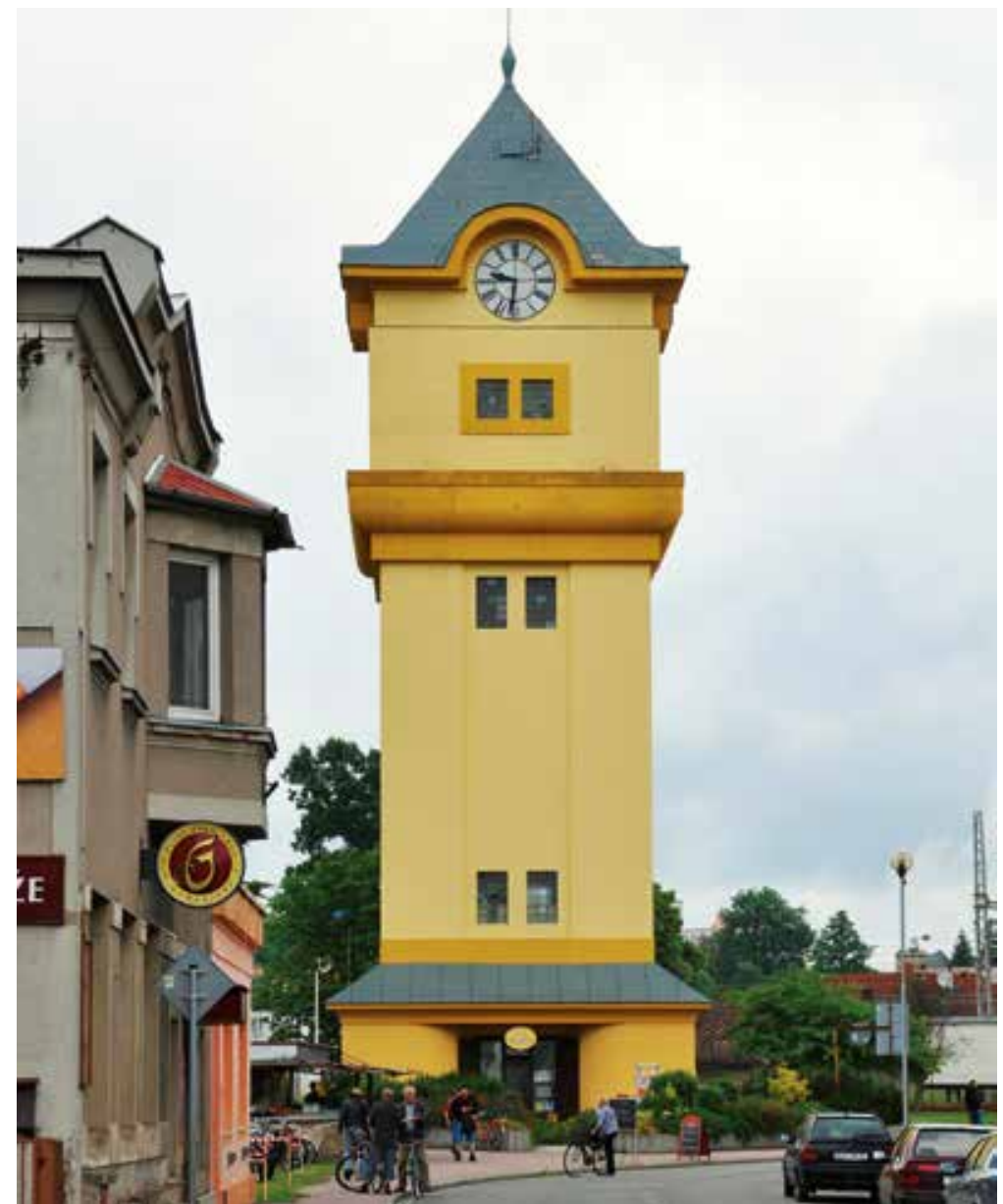

Obr. 9. Věžový vodojem v Týništi nad Orlicí s věžními hodinami (2012) Fig. 9. Elevated water tank in Týniště nad Orlicí with tower clock (2012)

Projekt vypracovala firma Karel Kress z Prahy a 12 metrů vysoký věžový vodojem, který byl jeho součástí, navrhl celý z režného cihelného zdiva (vzhledově podobný věžový vodojem postavený $v$ téže době firmou Kress se nachází v nedalekém Kovanci). Ocelová nádrž uložená na ocelových nosnících měla navržený objem $30 \mathrm{~m}^{3}$. Projekt se na konec nerealizoval, resp. k vybudování vodovodu došlo až ve třicátých letech 20. století se zcela jiným věžovým vodojem navrženým firmou Matička [16].

\section{Týniště nad Orlicí}

V úvodu příspěvku bylo uvedeno, že se v pojednání nebudeme zabývat drobnými změnami při realizaci objektů věžových vodojemů v průběhu úredního a stavebního procesu. Tyto změny zpravidla neměly významné dopady na samotnou stavbu. Přesto uvedeme jeden zajímavý príklad, kdy změna v průběhu výstavby oproti původnímu návrhu měla zásadní vliv na autorství stavby.

V letech 1925-1928 došlo v Týništi nad Orlicí k výstavbě nového vodovodu, jehož součástí byl věžový vodojem o objemu $200 \mathrm{~m}^{3}$ a výšce 35 metrů. Projekt vodovodu i věžového vodojemu zpracovala již dřive uvedená firma inženýra Matičky. Jeho návrh však nebyl realizován a opět dostal přednost architekt František Janda. V tomto př́padě však nepůjde o nerealizovaný návrh Matičky, ale právě o návrh Jandy.

Jak dokládají archiválie uloženév Archivu architekturya stavitelství Národního technického muzea v Praze, byl původní návrh týnišťského vodojemu bez věžních hodin [17]. Pořízení hodin do vrcholu věže napadlo představenstvo města 
až v době výstavby vodojemu. Stavbyvedoucí byl natolik přesvědčen výborností tohoto nápadu, že bez projednání změny s projektantem nechal sám zalomit původně rovnou rímsu kolem budoucích ciferníků (obr. 9). Když projektant věže viděl dílo stavbyvedoucího, zřekl se autorství návrhu objektu věžového vodojemu. Zdánlivá drobná změna $v$ realizaci projektu tak měla poměrně zásadní dopad na pohled architekta vodojemu [18-21].

\section{ZÁVĚR}

Důvodů, proč bylo občas odstoupeno od původních návrhů projektů věžových vodojemů, bylo vícero. Pokud byl projekt dotčenými orgány nebo investorem shledán jako zbytečně stavebně náročný (což se v př́mé souvislosti také projevilo na nežádoucích vyšších finančních nákladech), byla hledána varianta konstrukčně jednodušší a levnější (drážní věžový vodojem Rybník). U některých konstrukčních řešení bylo shledáno, že riziko samotné realizace je velmi vysoké (Poděbrady a Kolín - kulová nádrž). Jelikož věžový vodojem, jakožto vertikální stavba, je často zdaleka viditelný, došlo v některých prípadech k přepracování projektu s cílem dosáhnout důstojnějšího vzhledu objektu ve vztahu k místu a době výstavby (Nový Hradec Králové, Bělá pod Bezdězem). Architekti také většinou zpracovali více návrhů, realizovat však bylo možno pouze jeden, takže celá řada studií zůstala pouze na výkresech (dochované návrhy architekta Františka Jandy pro Poděbrady). A podobně pak skončily také projekty, kdy k plánované výstavbě vodovodu nakonec z různých důvodů nedošlo (Zamachy, Bílá Hlína).

Posuzování hodnot, které mohly být změnou projektu věžového vodojemu ztraceny nebo naopak získány, je subjektivní. V prípadě drážního věžového vodojemu v Rybníku by původně navržená konstrukce dvou excentricky umístěných nádrží a kombinaci stěnové a skeletové konstrukce byla rozhodně zajímavější, než nakonec realizovaný jednoduchý válec. Navíc by se z pohledu stavebního jednalo o ojedinělé řešení na našem území. V návrhu projektu vodovodu obce Zamachy, který se realizoval později a s jiným vodojemem, bylo rovněž původní řešení z estetického hlediska zajímavější. Naproti tomu odstoupení od původních návrhů v prípadě Nového Hradce Králové a Bělé pod Bezdězem Ize považovat za správné a novým realizacím nelze nic vytknout. U Hráského kulové nádrže v Kolíně a v Poděbradech by sice mohla ve věžovém vodojemu na našem území vzniknout konstrukčně zcela ojedinělá nádrž, výhrady úředních orgánů však vycházely z tehdejších stavebních znalostí a zkušeností práce se železobetonem a uvedené obavy je nutno respektovat.

\section{Poděkování}

Přispěvek vznikl v rámci řešeni projektu Věžové vodojemy - identifikace, dokumentace, prezentace, nové využití (Program na podporu aplikovaného výzkumu a vývoje NAKI II, Ministerstvo kultury ČR, kód DG18P02OVV010).

\section{Literatura}

[1] Archiv Národního technického muzea, Belada Bohumil, ing. 1890-1941, karton 43, 93.

[2] SOUČEK, F. Strojní zařízení nové výtopny v České Třebové. Zprávy železničních inženýrů, odborný a stavovský list železničnich inženýrů československých XII, 1935, s. 78-79.

[3] NTM, MAS, AA, f. 443 Belada, Česká Třebová - Projekt zásobení stanice ČSD, identifikátor 184/ kt.093 (nerealizovaný návrh vodojemu).

[4] Státní okresní archiv Hradec Králové, Archiv města Hradec Králové 1225-1945, karton 558. i. č. 2372. Ing. Bohuslav Drahoš, úredně autorizovaný civilní inženýr stavební a stavitel, Vysoké Mýto 1861-1948, karton 8, i. č. 47. Okresníúrad Hradec Králové / 1850-1945, karton 931, i. č. 1991.

[5] Vodovody a kanalizace Hradec Králové, a. s. Dokumentace skutečného stavu - věžový vodojem Nový Hradec Králové. Vodojem se nachází na katastrálním území Třebeš, obec Hradec Králové, 2005.

[6] VLČEK, P. Encyklopedie architektů, stavitelů, zedníků a kameníků v Čechách. Praha, 2004, s. 275.
[7] PAVLÍK, O. Stručnáhistorie Mladoboleslavského vodárenstvílll. Mladá Boleslav, 2006, s. 101-117.

[8] PAVLIKK, O. Věžovévodojemy na Mladoboleslavsku, Mladá Boleslav, 2012, s. 71-74.

[9] ERNI, Č. Z historie vodáren: Vodovod v Bělé p. Bezdězem. Plyn a voda IX, číslo 1, 1929, s. 6-9.

[10] Mezi další objekty postavené podle návrhů architekta Františka Jandy (a neuvedené $v$ dalším textu příspěvku) patří napríklad věžové vodojemy v Jaroměři, Kouřimi, Pečkách nebo Bezdědicích.

[11] Doposud se nepodařilo dohledat původní Hráského návrh kulové nádrže. Vycházíme tak pouze z dostupných textových archivních podkladů.

[12] Státní okresní archiv Nymburk, Archiv města Poděbrady, i. č. 961.

[13] Čech. Dva dưležité sociální podniky v Kolíně, 1. Městský vodovod. In: Robert Marek, Věstník odboru klubu čsl. turistů v Kolíně - Vlastivědný sborník středního Polabí, Kolín, 1929, s. 134-137.

[14] NTM, MAS, AA, f. 93 Janda, Vodojem v Poděbradech (1927), identifikátor 20080728/04, LHB-A 22.04.21 (návrh nerealizovaného vodojemu, varianta A); identifikátor 20080728/04, LHB-A 22.04.21 (návrh nerealizovaného vodojemu, varianta B).

[15] PAVLÍK, O. Stručná historie Mladoboleslavského vodárenství IV. Mladá Boleslav, 2007, s. 100-107.

[16] PAVLÍK, O. Věžové vodojemy na Mladoboleslavsku, Mladá Boleslav, 2012, s. 78-80.

[17] Archiv Národního technického muzea, Janda František 1910-1935, karton 93.

[18] TOMAŠ́̌K, Š. Vodárenská věž. In: Týniště známé i neznámé, sborníček Spolku prátel města Týniště nad Orlicí. Týniště nad Orlicí, 2011.

[19] KOLDINSKÝ, L. (ed.). Týniště nad Orlicí - město v lesích, historie slovem a obrazem. Týniště nad Orlicí, 2002.

[20] KOLDINSKÝ, L. Voda je život. Zpravodaj Spolku prátel města Týniště nad Orlicí, č. 5, 2010 [online]. [vid. 5. zárí 2019]. Dostupné z: www.muzeum-tyniste.cz.

[21] VALCHÁŘOVÁ, V. (ed.). Industriální topografie/Královéhradecký kraj, Praha 2012, s. 54.

\section{Autoři}

Ing. Robert Kořínek, Ph.D.

凶robert.korinek@vuv.cz

\section{Ing. Alena Kristová}

凶alena.kristova@vuv.cz

Výzkumný ústav vodohospodářský T. G. Masaryka, v. v. i., pobočka Ostrava Příspěvek prošel lektorským řízením.

\section{UNREALIZED TOWER WATER TANKS}

\section{KORINEK, R.; KRISTOVA, A.}

TGM Water Research Institute, p.r.i., Ostrava Branch

Keywords: elevated water tank - unrealized design - project

This paper presents several cases of unrealized elevated water tank projects in the Czech Republic. It deals with the technical solution of unrealized objects and at the same time presents the reasons why the designers, official bodies or investors led to the search for another solution. In the end, it tries to reflect briefly on the values that were gained or lost by the implementation of new projects instead of the originally designed ones. 